\title{
TISZTELT IFJÚ REGIONALISTÁK!
}

Az MTA Regionális Tudományos Bizottság és az MTA Regionális Kutatások Központja Nyugat-magyarországi Tudományos Intézete 2000. június 1-2. között immár másodszor rendezi meg az Ifjú Regionalisták Konferenciáját.

A konferencia helyszíne: MTA RKK Nyugat-magyarországi Tudományos Intézete, Györ, Liszt F. u. 10.

A konferencia célja bemutatkozási lehetőséget adni a regionális tudományban és a kapcsolódó tudományterületeken (geográfia, közgazdaságtan, szociológia) dolgozó fiatal kutatóknak. A rendezvényen, terveink szerint, jelen lesznek a hazai regionális tudomány jeles képviselöi is.

A konferencián részt vehet bárki, aki maximum 3 éve rendelkezik $\mathrm{PhD}$. fokozattal, vagy doktori tanulmányai folyamatban vannak.

Amennyiben részt kíván venni a konferencián, elöadása szövegét kinyomtatva és lemezen 2000. április 30-ig kérjük elküldeni az alábbi címre:

Nárai Márta vagy Hardi Tamás

MTA RKK Nyugat-magyarországi Tudományos Intézet

9002 Györ, Pf. 420. Tel.: 96/516-576

E-mail: naraim@edo.rkk.hu vagy hardit@edo.rkk.hu

Terjedelem: maximum 10 oldal Word 6.0 formátumban, betüméret: 12 , sorköz: 1,5.

\section{Várjuk jelentkezését!}

Tisztelettel: Rechnitzer János DSc.
elnök

Györ, 2000. február 20.
Izsák Éva $\mathrm{PhD}$.

titkár 